\title{
EFFECTS OF SOIL AND WATER SALINITY ON pH, EC AND THE SELECTED ION CONTENTS IN DIFFERENT CROPS GROWN IN NON- SALINE AND SALINITY AFFECTED AREAS OF BANGLADESH
}

\author{
SHAMSUN NAHER ${ }^{* 1}$, MD. ABU BAKAR SIDDIQUE ${ }^{2}$, TAHMINA AFROZ ${ }^{1}$, AJIT MALLIK ${ }^{1}$, \\ ABDUS SAMAD ${ }^{1}$ AND MD. AMINUL AHSAN ${ }^{2}$ \\ ${ }^{1}$ Department of Chemistry, Jagannath University, Dhaka-1100, Bangladesh. \\ ${ }^{2}$ Bangladesh Council of Scientific and Industrial Research (BCSIR) Laboratories, \\ Dhaka, Bangladesh
}

Salinity intrusion is a growing problem in the coastal areas around the globe. Climate change associated hazards like sea level rise, cyclone and storm surge have been contributing to this problem. Currently, cyclones accompanied by storm surge and increased salinity intrusion into fresh water and soils are the most catastrophic phenomena for coastal communities of Bangladesh, especially in Satkhira, a vulnerable coastal district. In last decade, number of cyclonic events from Bay of Bengal increased. Cyclone Sidr in 2007, cyclones Nargis and Reshmi in 2008 and cyclone Aila in 2009 caused huge damage. The government of People's Republic of Bangladesh estimated that it directly affected about five million families and crops of about 0.7 million hectares (DMB 2010). According to Bangladesh Bureau of Statistics, Sidr caused damage to more than 0.1 million tons of rice crop in Khulna (BBS 2010). Cyclone and storm surges force saline water into agricultural lands along coast, which damages crops in year of cyclone hits and for several years afterwards. This happened in area Shyamnagar Upazila under Satkhira district, studied in this present research. Saline water intrusion caused by cyclone Aila in 2009 led to loss and damage to rice crops in this area. Some recent studies indicated that salinity intrusion in both soil and water might increase further because of escalating intensity of cyclone and storm surge (SRDI 2010 and Rabbani et al. 2010). Coastal rice crops in Asia, for instance, are frequently affected by exposure to sea water brought in by cyclones around the Indian Ocean (Sultana et al. 2001). Salinity in Bangladesh river networks is reasonably well understood, with empirical and physically based study. Sea-level rise is likely to play a significant role in increasing salinity in natural drinking water sources in the future (Aerts et al. 2000 and Khan et al. 2011). The present study was undertaken to calculate soil, water, crops and salinity balances for different regions of Bangladesh that differ widely in water availability and the salt contents of the irrigation water. The prime aim was to study the impact of salinity on some selected ion contents such as $\mathrm{Na}, \mathrm{K}, \mathrm{Ca}, \mathrm{Mg}$, and $\mathrm{Cu}$ present in soil, water and crop samples.

Selection of the sampling area and sample collection: The study was conducted in four villages under Unions at Shyamnagar, Tala and chitalmari Upazila in Satkhira and Bagerhat District (salinity affected); Tongbari under Munshiganj District (non-saline).

${ }^{*}$ Corresponding address: Email: shamsunnaher2002@yahoo.com 
Satkhira and Tala are exposed coastal area in South West region under Khulna division of Bangladesh. Samples were collected from the field and were carried to laboratory in plastic bag. In laboratory, they were washed with deionized water to remove dirt. Separated parts were dried in air and at lower oven drying temperature $80^{\circ} \mathrm{C}$ (Jarrett 1983) for few hours until constant weight was attained. After cooling samples were grinded and sieved. They were then preserved for analyses in air tight plastic bag.

Sample preparation for laboratory analysis: Reagent grade $\mathrm{HClO}_{4}$ and $\mathrm{HNO}_{3}$ were procured from E. Merck, Germany. Certified standard stock solutions of nutrients were obtained from Varian, Australia for calibration purpose. All working solutions were also prepared in distilled water. Prior to analysis samples were digested with conc. $\mathrm{HNO}_{3}$ and $\mathrm{HClO}_{4}$ (2:1) mixture in acid digestion bomb (Model 4749A). Na and K were analyzed by flame photometer and other inorganic nutrients were measured by AAS. Salinity, $\mathrm{pH}$ and conductivity were measured by HACH Sension 156 portable multi meter.

The chemical parameters like $\mathrm{pH}$, Electrical conductivity and salinity of water and soil samples are presented in Table 1 . Concentrations of $\mathrm{Na}, \mathrm{K}, \mathrm{Ca}, \mathrm{Mg}, \mathrm{Cu}$ and $\mathrm{Zn}$ in different samples collected from various salinity and non-saline areas are presented in Tables 2-3. Concentrations in 12 crop samples varied within the range of $\mathrm{Na}$ (1796 $8362 \mathrm{mg} / \mathrm{kg}), \mathrm{K}(9710$ - $48921 \mathrm{mg} / \mathrm{kg}), \mathrm{Mg}(433$ - $4660 \mathrm{mg} / \mathrm{kg}), \mathrm{Ca}(415$ - $7477 \mathrm{mg} / \mathrm{kg})$, $\mathrm{Cu}(16-46 \mathrm{mg} / \mathrm{kg})$ and $\mathrm{Zn}(5-11 \mathrm{mg} / \mathrm{kg})$.

The $\mathrm{pH}$ of the collected water samples ranged from 6.75 to 7.35 with an average value of 7.05. The highest and the lowest $\mathrm{pH}$ values were detected respectively at Tala area $(\mathrm{pH}=$ $7.35)$ and Shymnagar $(\mathrm{pH}=6.75)$. The $\mathrm{pH}$ values of the soil samples ranged from 6.50 to 7.50 with an average value of 7 . The highest $\mathrm{pH}$ value was recorded at Tala $(\mathrm{pH}=7.50)$ and the lowest $\mathrm{pH}$ value was found at Tangbari $(\mathrm{pH}=6.50)$. According to the standard value set by the Guide to the Environmental Conservation Act 1995 and Rules 1997, for irrigation and drinking water purposes the value of $\mathrm{pH}$ is $6.5-8.4$. At the studied area, $\mathrm{pH}$ values of water and soil samples were found within the permissible limit. The EC values of the collected water samples ranged from 965 to $4570 \mu \mathrm{S} / \mathrm{cm}$ with an average value of $2527 \mu \mathrm{S} / \mathrm{cm}$. The highest and lowest EC values of water samples were recorded at Shymnagar and Tala, respectively. The EC value of the collected soil samples ranged from 150 to $3590 \mu \mathrm{S} / \mathrm{cm}$ with an average value of $1870 \mu \mathrm{S} / \mathrm{cm}$. The highest EC value was found at Shymnagar $(\mathrm{EC}=3590 \mu \mathrm{S} / \mathrm{cm})$ and the lowest value was recorded at Tala Upzila $(\mathrm{EC}=150 \mu \mathrm{S} / \mathrm{cm})$. The highest $\mathrm{EC}$ value of the region indicated that the area is salinity affected. So there can be harmful effect by salt concentration or salinity hazard in respect to EC. The salinity of the water and soil samples ranged from $0.2 \mathrm{ppt}$ to $20 \mathrm{ppt}$ and from $0.2 \mathrm{ppt}$ to $0.6 \mathrm{ppt}$, respectively. The highest salinity value was found at Shyamnagar in both water and soil samples. Result clearly showed Shyamnagar as more salinity affected area. The lowest values were found at Munshiganj (0.2) and Tala (0.4 ppt) for water and soil samples respectively evinced that soil contained less amount of salt than that of water sample. 
Table 1. Chemical parameters of soil and water samples collected from sampling areas.

\begin{tabular}{ccccc}
\hline $\begin{array}{c}\text { Sampling } \\
\text { Locations }\end{array}$ & Sample types & $\mathrm{pH}$ & Conductivity $(\mu \mathrm{S} / \mathrm{cm})$ & Salinity $(\mathrm{ppt})$ \\
\hline Tala & & 7.35 & 646 & 0.3 \\
Shyamnagar & \multirow{2}{*}{ Water } & 6.75 & 4575 & 20.0 \\
Chitalmari & & 7.15 & 1250 & 0.6 \\
Tangibari & & 7.04 & 484 & 0.2 \\
Tala & & 7.50 & 150 & 0.2 \\
Shyamnagar & & 6.90 & 3590 & 0.6 \\
Chitalmari & \multirow{2}{*}{ Soil } & 7.12 & 318 & 0.3 \\
Tangibari & & 6.50 & 780 & 0.4 \\
\hline
\end{tabular}

Sodium concentration of the collected water and soil samples ranged from 2 to 480 $\mathrm{mg} / \mathrm{kg}$ and 1389 to $11160 \mathrm{mg} / \mathrm{kg}$ respectively. The highest value of $\mathrm{Na}$ in water sample was found in Shyamnagar and the lowest value was found in Tangibari. The highest value of $\mathrm{Na}$ in soil was recorded at Shymnagar and the lowest value was recorded at Tala. Potassium and magnesium contents were highest $(9438$ and $13821 \mathrm{mg} / \mathrm{kg}$ ) in Chitalmari soil samples and the lowest values were recorded $(0.19$ and $0.65 \mathrm{mg} / \mathrm{kg})$ in Tala water samples. Calcium content was found highest $(12578 \mathrm{mg} / \mathrm{kg})$ in Tala soil samples and the lowest $(1.25 \mathrm{mg} / \mathrm{kg}$ ) in Tala water samples. $\mathrm{Cu}$ and $\mathrm{Zn}$ content (48 and $88 \mathrm{mg} / \mathrm{kg}$ ) were highest in Chitalmari soil and the least $(0.003 \& 0.0013 \mathrm{mg} / \mathrm{kg})$ in Shymnagar and Tala water samples respectively (Table 2).

Table 2. Concentrations of selected ion contents of soil and water samples collected from sampling areas.

\begin{tabular}{|c|c|c|c|c|c|c|c|}
\hline \multirow{2}{*}{ Location } & \multirow{2}{*}{$\begin{array}{l}\text { Sample } \\
\text { Type }\end{array}$} & \multicolumn{6}{|c|}{ Concentration of ion contents $(\mathrm{mg} / \mathrm{kg})$} \\
\hline & & $\mathrm{Na}$ & $\mathrm{K}$ & $\mathrm{Mg}$ & $\mathrm{Ca}$ & $\mathrm{Cu}$ & $\mathrm{Zn}$ \\
\hline \multirow{3}{*}{ Tala } & \multirow{3}{*}{$\begin{array}{c}\text { Soil (S-1) } \\
\text { Water (W-1) }\end{array}$} & 1389 & 6932 & 9822 & 12578 & 26 & 66 \\
\hline & & 8 & 0.2 & 0.7 & 1 & 0.003 & 0.001 \\
\hline & & 11160 & 6776 & 10270 & 5578 & 12 & 72 \\
\hline Shyamnagar & Soil(S-2) & 480 & 14 & 50 & 17 & BQL & 0.002 \\
\hline \multirow{2}{*}{ Chitalmari } & Soil(S-3) & 2352 & 9438 & 13821 & 11844 & 48 & 88 \\
\hline & Water(W-3) & 10 & 0.8 & 0.9 & 4 & BQL & 0.004 \\
\hline \multirow[t]{2}{*}{ Tangibari } & $\begin{array}{l}\text { Soil(S-4) } \\
\text { Sold }\end{array}$ & 1873 & 6856 & 12159 & 7364 & 44 & 14 \\
\hline & & 2 & 1.5 & 0.7 & 2 & BQL & 0.04 \\
\hline
\end{tabular}

$\mathrm{BQL}=$ below quantification limit

Among twelve different crop samples, bitter lemon of Tala $(8363 \mathrm{mg} / \mathrm{kg})$ followed by cucumber of Shyamnagar $(8335 \mathrm{mg} / \mathrm{kg})$ recorded for the maximum $\mathrm{Na}$ content and Tangibari potatoes were recorded for the minimum Na concentration $(1796 \mathrm{mg} / \mathrm{kg}$ ). Bitter lemon (Shymnagar) and cucumber (Tangibari) were found to contain the highest and least amounts (48921 and $9711 \mathrm{mg} / \mathrm{kg}$ ) of $\mathrm{K}$ content (Table 3). Both the $\mathrm{Mg}$ and $\mathrm{Ca}$ 
contents were recorded to be highest in cucumber of Shymnagar area (4660 and 7478 $\mathrm{mg} / \mathrm{kg}$ ). In Cucumber and Potato of Tala area minimum concentrations (434 and 416 $\mathrm{mg} / \mathrm{kg}$ ) of $\mathrm{Mg}$ and $\mathrm{Ca}$ respectively. On the other hand in Bitter lemon of Tala area maximum $\mathrm{Zn}$ and $\mathrm{Cu}$ contents (46.95 and $11.27 \mathrm{mg} / \mathrm{kg}$ ) were recorded. Potatoes contained minimum concentrations of $\mathrm{Zn}$ and $\mathrm{Cu}(16.74$ and $5.54 \mathrm{mg} / \mathrm{kg}$ ). Sampling locations with the higher electrical conductivity leads to high salinity. Shyamnagar was found to be most salinity affected area. Studied ion concentrations were found higher in soil than those of water samples and the higher concentrations were recorded in salinity affected areas than those of non-salinity affected areas. When the salt concentration is higher in the soil, water moves from plant into soil. When salts accumulate in soils, problems arise for two main reasons: the soil becomes less permeable and salt damages. Especially high $\mathrm{Na}$ concentration affects soil and can lead to sodic soil condition. High $\mathrm{Ca}, \mathrm{Mg}$ and $\mathrm{Zn}$ contents were recorded in samples. If $\mathrm{Ca}$ and $\mathrm{Mg}$ present in large quantities encounter the effect of $\mathrm{Na}$ and help to maintain good soil properties.

Table 3. Concentrations of ions in crop samples collected from sampling areas.

\begin{tabular}{lcccccc}
\hline \multirow{2}{*}{ Samples } & \multicolumn{7}{c}{ Concentration of ionic contents $(\mathrm{mg} / \mathrm{kg})$} \\
\cline { 2 - 7 } & $\mathrm{Na}$ & $\mathrm{K}$ & $\mathrm{Mg}$ & $\mathrm{Ca}$ & $\mathrm{Zn}$ & $\mathrm{Cu}$ \\
\hline S-1: Potato(Tala) & 2925 & 14535 & 960 & 416 & 19.86 & 5.64 \\
S-2: Potato(Shyamnagar) & 3774 & 23799 & 1401 & 721 & 25.15 & 7.47 \\
S-3: Potato(Chitalmari) & 3549 & 25822 & 1460 & 425 & 16.02 & 5.54 \\
S-4: Potato(Tangibari) & 1796 & 11159 & 1095 & 463 & 16.74 & 5.73 \\
S-5: Cucumber(Tala) & 6026 & 38605 & 434 & 684 & 45.39 & 7.66 \\
S-6: Cucumber(Shyamnagar) & 8335 & 40693 & 4660 & 7478 & 43.68 & 8.01 \\
S-7: Cucumber(Chitalmari) & 8065 & 29385 & 3200 & 6055 & 37.23 & 6.79 \\
S-8: Cucumber(Tangibari) & 3512 & 9711 & 759 & 1186 & 22.59 & 6.32 \\
S-9: Bitter Lemon (Tala) & 8363 & 43434 & 3115 & 1840 & 46.95 & 11.27 \\
S-10: Bitter Lemon & 4847 & 48921 & 2921 & 2838 & 34.76 & 7.67 \\
(Shyamnagar) & & & & & & \\
S-11: Bitter Lemon & 7347 & 34841 & 2283 & 1704 & 29.79 & 6.99 \\
(Chitalmari) & 8024 & 34047 & 2644 & 3104 & 31.26 & 7.78 \\
S-12: Bitter Lemon (Tangibari) & & & & & &
\end{tabular}

\section{Acknowledgements}

The authors express their gratitude to Dhaka laboratories, BCSIR to create a scope to analyze the samples at the laboratories during this research work.

\section{References}

Aerts, L.J., A. Hasan, H.H.G. Savenije and M.F. Khan. 2000. Using GIS tools and rapid assessment techniques for determining salt intrusion: stream a river basin management intrusion. Physics ChemEarthBHydrol Oceans Atoms. 25: 265273.

Jarrett, P.M. 1983. Testing of Peats and Organic Soils, ASTM STP 820, American Society for Testing and Materials: Philadelphia, 241. 
Khan, A.E., A. Ireson, S. Kovats, S. K. Mojumder, A. Khusru, A. Rahman and P. Vineis. 2011. Environ Health Perspect. Sep; 119(9): 1328-1332.

BBS (Bangladesh Bureau of Statistics). 2010. Statistics Division, Ministry of Planning, Government of Bangladesh. Yearbook of Agricultural Statistics of Bangladesh.

DMB (Disaster Management Bureau). 2010. Disaster Management and Relief Division, Ministry of Food and Disaster Management, Dhaka, Bangladesh. National Plan for Disaster Management 2010-2015.

Rabbani, M.G., A.A. Rahman and N. Islam. 2010. 'Climate change and sea level rise' Coastal Zone and Climate Change, 17-29.

Sultana, N., T. Ikeda and M.A. Kashem. 2001. Effect of foliar spray of nutrient solutions on photosynthesis, dry matter accumulation and yield in seawater-stressed rice. Environ. Exp. Bot. 46: 129-140.

SRDI (Soil Resource Development Institute). 2010. Ministry of Agriculture, Dhaka, Bangladesh. Saline Soils of Bangladesh. 